Azaria, et al/Jurnal Ekonomi Syariah Teori dan Terapan Vol. 6 No. 8 Agustus 2019: 1733-1740;

IDENTIFIKASI HOLDING PERIOD BANK UMUM SYARIAH DI BURSA EFEK INDONESIA

\title{
IDENTIFIKASI HOLDING PERIOD BANK UMUM SYARIAH DI BURSA EFEK INDONESIA ${ }^{1}$
}

\author{
Ainun Azaria \\ Departemen Ekonomi Syariah - Fakultas Ekonomi dan Bisnis - Universitas Airlangga \\ Email: ainunazaria4@gmail.com \\ Sylva Alif Rusmita \\ Departemen Ekonomi Syariah - Fakultas Ekonomi dan Bisnis - Universitas Airlangga \\ Email: sylvalifr@feb.unair.ac.id
}

\begin{abstract}
:
This study aims to determine the effect of bid-ask spread, stock return and trading volume on the holding period of sharia commercial bank shares. This study uses a purposive sampling method, and from the specified criteria there were 3 Sharia Commercial Banks obtained, that meet the criteria and can be used as samples. The data used is in the form of daily reports obtained from the IDX website. This study uses a quantitative approach with descriptive analysis analysis techniques. The results of this study indicate that the stock holding period of Islamic Commercial Banks can be seen based on the bid-ask spread, stock return and trading volume.
\end{abstract}

Keywords: Holding Period Saham, Bid-Ask Spread, Return Saham, Volume Perdagangan.

\section{PENDAHULUAN}

Investasi adalah penanaman modal dalam satu atau lebih pada aktiva dengan sebuah harapan untuk memperoleh suatu keuntungan di masa yang akan datang. Seorang investor mempunyai kebebasan dalam memilih jenis saham, membeli jumlah lembar saham serta dalam menentukan lamanya memegang asset perusahaan yang telah go public. Apabila seorang investor memprediksi saham pada perusahaan yang dibelinya dapat menguntungkan, maka investor akan cenderung untuk menahan sahamnya dalam jangka waktu yang panjang, dengan harapan bahwa harga jual pada perusahaan tersebut lebih tinggi di masa yang akan datang, dan begitu juga sebaliknya. Hal tersebut dilakukan untuk memperoleh gain yang sebesar-besarnya dari investasi yang dilakukannya dan untuk meminimalkan terjadinya sebuah risiko yang akan dihadapinya. Hal ini sejalan dengan prinsip syariah yang telah sepakat dengan perilaku seorang investor yang mengholding saham lama dengan jangka waktu yang panjang, bukan untuk spekulasi goreng menggoreng saham. Oleh karena itu, lamanya seorang investor dalam mengholding saham atau memegang sahamnya untuk jangka waktu terntentu merupakan hal yang menarik untuk diteliti.

Hal yang menarik pada saat ini adalah adanya saham-saham yang benar-benar berbasiskan dengan prinsip syariah. Perusahaan yang berbasiskan benar-benar syariah adalah Bank Umum Syariah (BUS). Contoh holding period bank

\footnotetext{
${ }^{1}$ Jurnal ini merupakan bagian dari skripsi Ainun Azaria, NIM: 04151 1433082, yang diuji pada tanggal 25 Juni 2019.
} 
umum syariah pada bulan januari tahun 2019 paling lama mengholding sahamnya 12 hari yang ditunjukkan oleh Gambar 1 mengalami kondisi yang berfluktuatif.

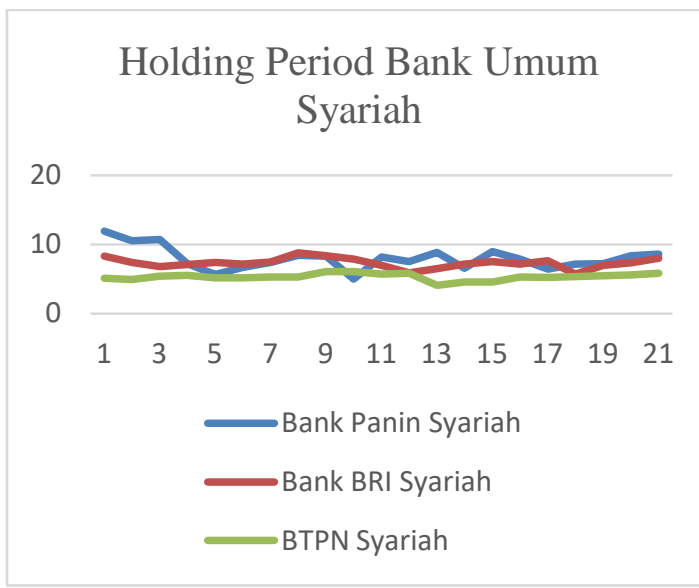

Sumber: data diolah

Gambar 1.

\section{Fluktuasi Holding Period Saham Bank Umum Syariah}

Perkembangan pasar modal syariah di Indonesia sendiri menunjukkan pergerakan yang semakin baik, ditandai dengan adanya Jakarta Islamic Index (JII). Selain itu, juga terdapat indeks syariah baru yaitu Indeks Saham Syariah Indonesia (ISSI).

Pasar modal syariah berbeda dengan pasar modal konvensional. Hal yang paling membedakan yaitu pasar modal syariah harus menghindari praktik spekulasi yang mengarah pada perjudian. Seperti yang telah dijelaskan dalam AlQur'an Surat Al-Maidah Ayat 90, sebagai berikut:

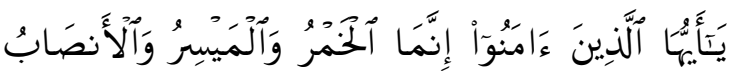

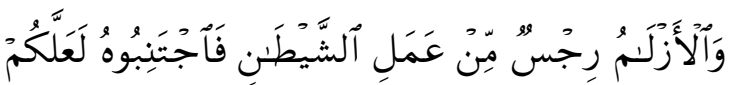
تُفْلحُونَ
Yaaayyuhaal-ladziina aamanue innama alkhamru walmaisiru walanshaabu walazlaamu rijsun min 'amalisy-syaithaani faajtanibuuhu la'allakum tuflihuun.

Artinya: "Hai orang-orang yang beriman, sesungguhnya (meminum) khamar, berjudi, (berkorban untuk) berhala, mengundi nasib dengan panah, adalah termasuk perbuatan syaitan. Maka jauhilah perbuatan-perbuatan itu agar kamu mendapat keberuntungan." (Q.S Al-Maidah : 90).

Berdasarkan dari penelitian terdahulu dan uraian latar belakang di atas mengenai faktor yang mempengaruhi holding period. Menunjukkan bahwa adanya sebuah hasil ketidakpastian dan adanya tidak konsistennya atas hasil dari penelitian sebelumnya. Oleh karena itu peneliti ingin melakukan sebuah penelitian mengenai faktor yang mempengaruhi holding period, dengan penelitian yang berjudul "IDENTIFIKASI HOLDING PERIOD BUS DI BEI." Maka rumusan masalah dalam penelitian ini adalah bagaimanakah holding period bank umum syariah yang terindeks di BEI. Adapun tujuan dari penelitian ini untuk mengetahui holding period bank umum syariah yang terindeks di BEl. Hasil penelitian ini diharapkan dapat memberikan informasi dan kontribusi bagi berbagai pihak yang berkepentingan.

\section{LANDASAN TEORI DAN} PENGEMBANGAN HIPOTESIS Investasi Syariah 
Azaria, et al/Jurnal Ekonomi Syariah Teori dan Terapan Vol. 6 No. 8 Agustus 2019: 1733-1740; IDENTIFIKASI HOLDING PERIOD BANK UMUM SYARIAH DI BURSA EFEK INDONESIA

Investasi merupakan suatu artian dari suatu kata yang berasal dari bahasa inggris, yaitu investment. Kata investasi dalahsebuah kata dasar dari investment, di mana mempunyai sebuah arti suatu penanaman. Menurut Tandelin (2010: 2) investasi merupakan sebagai komitmen atas pengeluaran sejumlah dana atau sumber daya lainnya yang dimiliki oleh seorang investor atau sebuah perusahaan yang dilakukan pada saat ini dengan tujuan untuk memperoleh sejumlah keuntungan di masa yang akan mendatang. Sedangkan menurut Jogiyanto (2013:5) investasi merupakan menunda dari suatu konsumsi yang dilakukan saat ini untuk dimasukan ke dalam aktiva produktif selama periode tertentu yang di mana kemudian digunakan untuk suatu konsumsi di masa yang akan datang.

Definisi investasi yang telah disampaikan di atas merupakan suatu pengertian investasi dalam konsep konvensional. Apabila di dalam Islam Ryandono (2009: 21), mengemukakan bahwa investasi yang menurut syariah Islam adalah pengorbanan sumber daya yang dimiliki di masa sekarang untuk memperoleh sesuatu hasil yang pasti, dan dengan adanya harapan untuk memperoleh suatuhasil yang lebih besar di masa yang akan datang, baik secara langsung maupun tidak langsung, namun tetap dalam aturan yang sesuai dengan prinsip syariah Islam dengan secara keseluruhan.

\section{Saham Syariah}

Secara sederhana, saham dapat didefinisikan sebagai sertifikat yang menunjukkan bukti kepemilikan perusahaan dan pemegang saham memiliki hak klaim atas penghasilan dan aktiva dari suatu perusahaan. Fahmi dan Hadi (2009: 68) menyatakan bahwa saham merupakan tanda bukti penyertaan kepemilikan modal atau dana di suatu perusahaan. Sedangkan menurut Ridwan (2002: 381) saham merupakan suratberharga yang dikeluarkan oleh perusahaan yang berbentuk perseroan terbatas atau disebut emiten.

Jogiyanto (2013: 111 ) mengatakan bahwa suatu perusahaan mengeluarkan bentuksaham dan menjual hak dari kepemilikannya, tetapi hanya mengeluarkan satu kelas saham biasa atau sering disebut dengan saham biasa (common stock). Menurut Mishkin dan Eakins (2006: 28) mengemukakan bahwa saham merupakan sekuritas yang menyatakan tentang pendapatan aktiva dari suatu perusahaan.

Pengertian yang telah dipaparkan di atas merupakan pengertian dari saham konvensional. Sedangkan saham syariah salah satu bentuk dari saham biasa yang telah memiliki karakteristik khusus yang telah terkontrol dari dalam hal kehalalan pada ruang lingkup usahanya. Menurut Hidayat (2011: 78) yang dimaksud dengan saham syariah merupakan bukti kepemilikan dari suatu perusahaan yang 
Azaria, et al/Jurnal Ekonomi Syariah Teori dan Terapan Vol. 6 No. 8 Agustus 2019: 1733-1740; IDENTIFIKASI HOLDING PERIOD BANK UMUM SYARIAH DI BURSA EFEK INDONESIA

jenis usahanya, produk barangnya, jasa yang diberikan, dan akad serta cara yang dari tata pengelolaannya tidak bertentangan dengan prinsip-prinsip syariah (dan termasuk saham yang memiliki hak-hak istimewa).

\section{Holding Period}

Holding period merupakan merupakan rata-rata panjangnya waktu investor menahan saham perusahaan selama jangka waktu atau periode tertentu (Ratnasari dan Astuti, 2014). Keputusan investor untuk menahan sahamnya dipengaruhi oleh banyak faktor, seperti bid-ask spread, variance return, dan volume perdagangan. Pada saat berinvestasi seorang investor akan selalu mempertimbangkan adanya risiko yang akan dihadapi nanti untuk bias mendapatkan gain yang maksimal.

Jangka waktu investasi suatu saham setiap investor berbeda. Seorang investor cenderung akan menahan sahamnya dalam jangka waktu yang lebih lama apabila memprediksikan bahwa saham perusahaan yang dibelinya tersebut dapat menguntungkan. Dengan harapan bahwa harga jual saham tersebut lebih tinggi di masa yang akan datang. Sebaliknya, investor akan segera melepas/menjual saham yang dibelinya, jika diprediksikan bahwa harga saham tersebut akan mengalami penurunan (Helmy, 2008).

\section{METODE PENELITIAN}

Pendekatan Penelitian
Dalam penelitian ini jenis penelitian yang digunakan adalah penelitian kuantitatif dengan menggunakan pendekatan deskriptif, karena dalam penelitian ini data yang digunakan atau di intepretasikan berupa sebuah angkaangka.

Penelitian ini akan melihatholding period saham pada bank umum syariah yang terindeks di BEI. Analisis yang digunakan di dalam penelitian ini merupakan analisis deskriptif dengan menggunakan alat SPSS atau dengan model ordinary least square (OLS). Hal tersebut dilakukan oleh peneliti dikarenakan peneliti ingin mengetahui sejauh mana variabel bebas mempengaruhi variabel terikat.

\section{Populasi dan Sampel}

Menurut Sugiyono (2014: 80) yang dimaksud dari populsi merupakan wilayah dari generalisasi yang terdiri dari beberapa obyek atau subyek yang mempunyai kualitas dan karakteristik tertentu yang ditetapkan dan dipelajari yang kemudian akan ditarik sebuah kesimpulan. Dalam penelitian ini populasinya adalah bank umum syariah yang terindeks di Bursa Efek Indonesia.Pengambilan sampel dalam penelitian ini menggunakan teknik purposive sampling.Adapun kriteria dalam penepatan pengambilan sampel pada penelitian ini yaituBank Umum Syariah yang telah listing di Bursa Efek Indonesia.

\section{Pengumpulan Data}


Data adalah cerminan dari suatu variabel yang akan diukur menurut beberapa klasifikasinya. Data dapat diklasifikasikan berdasarkan dari beberapa kriteria, misalnya dari sifatnya, jenisnya, cara pengelolahannya, sumbernya dan waktu pengumpulannya.Dalam prosedur pengumpulan data yang digunakan pada penelitian ini yaitu pertama studi kepustakaan, yang dimaksud studi kepustakaan yaitu dengan cara mengumpulkan dari bebrapa informasi, jurnal, literatur review, dan teori-teori yang mempunyai relevansi dengan permasalahan yang sama dengan penelitian. Kedua penelitian terdahulu, melakukan dari segi penelitian dan peninjauan yang secara umum dengan tujuan memperoleh informasi mengenai permasalahan yang dibahas dalam penelitian ini. Dan yang ketiga pengumpulan data, penelitian ini datanya diperoleh dari data sekunder yang akan diperoleh dari website resmi Bursa Efek Indonesia yaitu IDX atau www.idx.co.id.

\section{Pengumpulan Data}

Data adalah cerminan dari suatu variabel yang akan diukur menurut beberapa klasifikasinya. Data dapat diklasifikasikan berdasarkan dari beberapa kriteria, misalnya dari sifatnya, jenisnya, cara pengelolahannya, sumbernya dan waktu pengumpulannya.Dalam prosedur pengumpulan data yang digunakan pada penelitian ini yaitu pertama studi kepustakaan, yang dimaksud studi kepustakaan yaitu dengan cara mengumpulkan dari bebrapa informasi, jurnal, literatur review, dan teori-teori yang mempunyai relevansi dengan permasalahan yang sama dengan penelitian. Kedua penelitian terdahulu, melakukan dari segi penelitian dan peninjauan yang secara umum dengan tujuan memperoleh informasi mengenai permasalahan yang dibahas dalam penelitian ini. Dan yang ketiga pengumpulan data, penelitian ini datanya diperoleh dari data sekunder yang akan diperoleh dari website resmi Bursa Efek Indonesia yaitu IDX atau www.idx.co.id.

\section{Definisi operasional}

\section{Holding period}

Holding Period merupakan variabel yang memberikan indikasi mengenai rata-rata dari panjangnya waktu investor untuk menahan sahamnya.

$$
\begin{aligned}
& \text { Hld Prd } \\
& =\frac{\text { Jumlah Saham Beredar }}{\text { Volume Transaksi Perdagangan }}
\end{aligned}
$$

\section{Bid-Ask Spread}

Bid-ask spread adalah selisih antara harga permintaan tertinggi (bid price) dengan harga penawaran terendah (ask spread) pada saham. Bid price merupakan harga tertinggi pada saham yang ditawarkan kepada seorang investor, sedangkan ask price merupakan harga terendah pada saham yang ditawarkan oleh seorang investor ketika 
suatu perusahaan atau investor akan melepas dan menjual sahamnya tersebut.

$$
B A=\frac{(\text { ask }- \text { bid })}{(\text { ask }+ \text { bid }) \times 0,5}
$$

Keterangan :

$\mathrm{BA}=$ Bid-ask spread pada saham I pada hari ke $-\dagger$

Ask = Harga penawaran jual saham pada harike - $\dagger$

Bid $=$ Harga penawaran beli saham pada hari ke $-\dagger$

\section{Return Saham}

Return saham merupakan pendapatan yang dinyatakan dalam persentase dari modal awal investasi. Pendapatan investasi dalam saham ini meliputi keuntungan jual beli saham, dimana jika terdapat keuntungan dalam jual beli saham tersebut disebut capital gain dan jika terjadi rugi dalam jual beli saham disebut capital loss. Return saham merupakan perbandingan antara harga saham hari sekarang dengan harga saham hari sebelumnya.

$$
\text { Return Saham }=\frac{P_{t}-P_{t-1}}{P_{t-1}}
$$

Keterangan :

$\mathrm{P}_{\dagger}=$ Harga Penutupan saham pada hari $\mathrm{ke}-\dagger$

$\mathrm{P}_{\mathrm{t}-1}=$ Harga Penutupan saham pada hari $k e-t-1$

\section{Volume Perdagangan}

Volume perdagangan merupakan jumlah saham atau surat berharga yang diperdagangkan di pasar modal secara harian. Volume perdagangan adalah rasio antara jumlah lembar saham yang diperdagangkan pada waktu tertentu terhadap jumlah saham yang beredar pada waktu tertentu.

\section{HASIL DAN PEMBAHASAN}

\section{Analisis Data dan Pembahasan}

Uji Deskriptif

Tabel 1.

Hasil Uji Deskriptif

\begin{tabular}{|l|l|l|l|l|}
\hline & Min & Max & Mean & Std.Dev \\
\hline LNHId & 2,80 & 13,31 & 6,91 & 1,43 \\
\hline BA & $-0,67$ & 2,00 & 0,05 & 0,30 \\
\hline Return & $-0,11$ & 0,14 & 0,01 & 0,02 \\
\hline VLM & 3920 & 1440 & 238,86 & 637,52 \\
\hline
\end{tabular}

Sumber: hasil olah data SPSS

Analisis deskriptif digunakan untuk memberikan gambaran mengenai variable dalam penelitian ini, yaitu variabel holding period, bid-ask spread, market value, dan variance return. Tabel 1 adalahhasil uji deskriptif. Berdasarkan pada Tabel 41 holding period terendahselama 2,80. Adapun holding period tertinggi yaitu selama 13,31. Secarakeseluruhan, rata-rata holding period semesteran dari sampel yang diteliti adalah 6,91. Nilai rata-rata dengan nilai maksimum yang dimiliki sampel lebih jauh bila dibandingkan dengan nilai minimumnya. Hal ini menunjukkan bahwa nilai holding period perusahaan banyak yang terletak di bawah nilai rata-rata, yang berarti investor tidak suka menahan kepemilikan atas sahamnya lebih lama.

Nilai bid-ask spread terendah yaitu sebesar -0,67. Adapun bid-ask spread tertinggisebesar 2,00. Besarnya rata-rata bid-ask spread pada sampel yang diteliti 
yaitu sebesar 0,05. Nilai rata-rata dengan nilai maksimum yang dimiliki sampel lebih jauh bila dibandingkan dengan nilai minimumnya. Hal ini menunjukkan bahwa nilai bid-ask spread banyak yang terletak dibawah nilai rata-rata.

Nilai return saham terendah yaitu sebesar -0,11. Adapun return saham tertinggi sebesar 0,14. Besarnya rata-rata return saham pada sampel yang diteliti yaitu sebesar 0,01 . Nilai rata-rata dengan nilai maksimum yang dimiliki sampel lebih jauh bila dibandingkan dengan nilai minimumnya. Hal ini menunjukkan bahwa nilai return saham banyak yang terletak di bawah nilai rata-rata.

Nilai volume perdagangan terendah yaitu sebesar 392. Adapun volume perdagangan tertinggi sebesar 1440. Besarnya rata-rata bid-ask spread pada sampel yang diteliti yaitu sebesar 238,86 . Nilai rata-rata dengan nilai maksimum yang dimiliki sampel lebih jauh bila dibandingkan dengan nilai minimumnya. Hal ini menunjukkan bahwa nilai bid-ask spread banyak yang terletak di bawah nilai rata-rata.

\section{v. SIMPULAN}

Berdasarkan hasil diatas dapat disimpulkan holding period bank umum syariah yang terindeks di BEl dapat dilihat berdasarkan bid-ask spread, return sahamn dan volume perdagangannya.

Penelitian ini mempunyai beberapa keterbatasan yaitu penelitian ini hanya menggunakan jangka waktu periode satu tahun, dikarenakan sampel penelitian ini pada bank umum syariah baru satu tahun perusahaannya listing pada bursa efek Indonesia. Saran yang dapat disampaikan berdasarkan kesimpulan yang telah diuraikan di atas adalah pertama bagi investor muslim yang akan melakukan sebuah investasi syariah di bursa efek Indonesia pada sektor perbankan, hendaknya memperhatikan atau mempertimbangkan bid-ask spread, return saham, dan volume perdagangan. Kedua penelitian selanjutnya untuk diharapkan menambah jumlah jangka waktu periode, menambah jumlah sampel dengan memperluas populasi, serta menambah variabelvariabel lain yang berkaitan dengan holding period di dalam penelitiannya.

\section{DAFTAR PUSTAKA}

Atkins, Allen B. dan Dyl, Edward A. 1997. Transaction costs and Holding Period for common stocks. The Journal of Finance. Vol. 3 No. 1.

Arma, VisitaYales. (2013). Faktor Penentu Holding Period Saham LQ45 di Bursa Efek Indonesia. Journal of Business and Banking. Vol. 3, No. 2.

Chung, S. \& Wei, P. 2005. The relationship between bid-ask spreads and holding period: the case of Chinese $A$ and $B$ Shares. Global Finance Journal. Vol. 15 : 239-249. Hidayat, Taufik. 2011. Buku Pintar Investasi Syariah. Jakarta: PT. Transmedia. Huda, Nurul dan Mustafa Edwin Nasution. 2007. Investasi pada Pasar Modal 
Azaria, et al/Jurnal Ekonomi Syariah Teori dan Terapan Vol. 6 No. 8 Agustus 2019: 1733-1740; IDENTIFIKASI HOLDING PERIOD BANK UMUM SYARIAH DI BURSA EFEK INDONESIA

Syariah. Jakarta: Prenada Media Grup.

Husnan, Suad. 2009. Dasar - Dasar Teori Portofolio dan Analisis Sekuritas. Edisi Keempat. Yogyakarta: LPP STIM YKPN.

Ratnasari, Desy dan Dewi Astuti. (2014). Pengaruh Bid-Ask Spread, Market Value, dan Variance Return Terhadap Holding Period. Jurnal Finiesta. Vol. 2, No. 1.

Ryandono, Muhammad Nafikh H. 2009. Bursa Efek dan Investasi Syariah. Jakarta: Serambi.

Santoso, Eko Budi. 2008. Analisis Pengaruh Transaction Cost Terhadap Holding Period Saham Biasa.
Jurnal Riset Akuntansi dan Keuangan. Vol. 4, No. 2.

Sugiyono. 2014. MetodePenelitianBisnis. Bandung: Alfabeta.

Sutedi, Adrian. 2011. Pasar Modal Syariah: Sarana Investasi Kevangan Berdasarkan Prinsip Syariah. Jakarta: Sinar Grafika.

Stoll. Hans R. 1989. Infering The Componen of The Bid-Ask Spread: Theory And Emprical Test. The Journal of Finance. Vol. 4, No. 1.

Tandelilin, Eduardus. 2001. Portofolio dan InvestasiTeori dan Aplikasi. Yogyakarta :Kanisius.

www.idx.co.id 